\title{
Nine New Farnesylphenols from the Basidiomycete Albatrellus Caeruleoporus
}

\author{
Liang-Yan Liu $\cdot$ Zheng-Hui Li $\cdot$ Gang-Qiang Wang • \\ Kun Wei $\cdot$ Ze-Jun Dong $\cdot$ Tao Feng $\cdot$ \\ Gen-Tao Li $\cdot$ Yan Li $\cdot$ Ji-Kai Liu
}

Received: 16 March 2014/ Accepted: 10 April 2014/Published online: 23 April 2014

(C) The Author(s) 2014. This article is published with open access at Springerlink.com

\begin{abstract}
Nine previously-unreported farnesylphenols, involving eight neogrifolin derivatives (1-8) and one grifolin analogue (9), together with three known compounds, were isolated from the fruiting bodies of the mushroom Albatrellus caeruleoporus. Their structures were elucidated as $(S)$-17-hydroxy-18,20-ene-neogrifolin (1), $(S)$-18,19-dihydroxyneogrifolin (2), (S)-9-hydroxy-10,22-ene-neogrifolin (3), (9S,10R)-6,10-epoxy-9-hydroxyneo grifolin (4), (9S,10R)-6,9-epoxy10-hydroxyneogrifolin (5), (-)-13,14-dihydroxyneogrifolin (6), albatrelin G (7), albatrelin H (8), and one grifolin analogue, $(S)$-10-hydroxygrifolin (9), grifolin (10), neogrifolin (11), and albatrellin (12) by extensive spectroscopic analyses and chemical methods. Compounds $\mathbf{7}$ and $\mathbf{8}$ showed weak cytotoxic activity to cell lines HL-60, SMMC-7721, A-549, and MCF-7, in vitro.
\end{abstract}

Keywords Albatrellus caeruleoporus $\cdot$ Mushroom · Polyporaceae $\cdot$ Farnesylphenols

\section{Introduction}

Mushrooms of the Albatrellus genus are well known for producing farnesylphenols, such as grifolin, neogrifolin and their derivatives [1-6]. Farnesylphenols can be divided into two groups: monomers of grifolin and neogrifolin derivatives, and dimers of them. The monomers were reported to possess diverse biological activities, such as anti-oxidative activity [3], anti-microbial effect [7, 8],

Electronic supplementary material The online version of this article (doi:10.1007/s13659-014-0015-5) contains supplementary material, which is available to authorized users.

L.-Y. Liu · Z.-H. Li · G.-Q. Wang · K. Wei · Z.-J. Dong ·

T. Feng · G.-T. Li · Y. Li · J.-K. Liu $(\bowtie)$

State Key Laboratory of Phytochemistry and Plant Resources in

West China, Kunming Institute of Botany, Chinese Academy of

Sciences, Kunming 650201, Yunnan, China

e-mail: jkliu@mail.kib.ac.cn

L.-Y. Liu

University of the Chinese Academy of Sciences, Beijing 100049,

China promotion of melanin synthesis [9], activity on human and rat vanilloid receptor 1 [10] inhibition of tumor-cell growth [11], and inhibition of nitric oxide production in RAW 264.7 cells [4]. And the dimers (fungal pigments) are regarded as the chemical base of the conspicuous fruiting bodies of these mushrooms [2, 4].

Albatrellus caeruleoporus is a nontoxic and inedible mushroom distributed in central and southwestern China. Its fruiting body is white with a light blue skin on the pileus [12]. Previous investigation on A. caeruleoporus led to three grifolin monomers, grifolin, neogrifolin, and grifolinone A, and one dimer, grifolinone B [4]. Their nitorite production inhibitory activities were reported [4]. In order to find more farnesylphenols with biological activities a systematic phytochemical investigation on the basidiomycete A. caeruleoporus was performed, it led to isolate eight new neogrifolin derivatives (1-8), a new grifolin analogue (9), grifolin (10) [10], neogrifolin (11) [10], and albatrellin (12) [2]. Their structures were identified by a combination of extensive spectroscopic analyses (NMR, MS, IR, UV, and $[\alpha]_{\mathrm{D}}$ ) and chemical methods. Compounds 1-9 were oxygenated farnesylphenols, which 
<smiles>CC(=O)[C@H](O)CC/C=C/C/C=C/C(C)=C/Cc1c(C)cc(O)cc1O</smiles><smiles>C/C(=C\Cc1c(C)cc(O)cc1O)CC/C=C(\C)CC[C@@H](O)C(C)(C)O</smiles><smiles>C=C(CC/C=C(\C)CCC=C(C)C)[C@H](O)Cc1c(C)cc(O)cc1O</smiles><smiles>CC(C)=CCC/C(C)=C/CC[C@]1(C)Oc2cc(O)cc(C)c2C[C@H]1O</smiles><smiles>CC(C)=CCC/C(C)=C/CC[C@](C)(O)[C@H]1Cc2c(C)cc(O)cc2O1</smiles><smiles>CC(C)=CCC[C@](C)(O)[C@H](O)CC/C(C)=C/Cc1c(C)cc(O)cc1O</smiles><smiles>C=C(CCC=C(C)C)[C@H]1CC[C@@](C)(O)C[C@H]1c1c(C)cc(O)cc1O</smiles>

7<smiles>CC(C)=CCCC(C)(O)[C@H]1CC[C@@]2(C)C[C@H]1c1c(C)cc(O)cc1O2</smiles>

8<smiles>CC(C)=CCC/C(C)=C/CC[C@](C)(O)CCc1c(O)cc(C)cc1O</smiles>

9<smiles>CC(C)=CCC/C(C)=C/CC/C(C)=C/Cc1c(O)cc(C)cc1O</smiles>

grifolin<smiles>CC(C)=CCC/C(C)=C/CC/C(C)=C/Cc1c(C)cc(O)cc1O</smiles>

neogrifolin

Fig. 1 Chemical structures of compounds 1-9

have not previously been reported in the Albatrellus genus, and might be regarded as a chemotaxonomic evidence for identification of this mushroom. All new compounds were tested in a cytotoxicity assay in vitro against five human cancer cell lines.

\section{Results and Discussion}

The chloroform-methanol (1:1) extract of fruiting bodies of A. caeruleoporus was subjected to silica gel, RP-18, Sephadex LH-20 column chromatography (CC), and semipreparative HPLC purification steps to give compounds 1-12 (Fig. 1). Compounds 1-8, namely $(S)-17-$ hydroxy-18,20-ene-neogrifolin (1), (S)-18,19-dihydroxyneogrifolin (2), (S)-9-hydroxy-10,22-ene-neogrifolin (3), $(9 S, 10 R)-6,10$-epoxy-9-hydroxyneogrifolin (4), $(9 S, 10 R)$ 6,9-epoxy-10-hydroxyneogrifolin (5), (-)-13,14-dihydroxyneogrifolin (6), albatrelin $\mathrm{G}(\mathbf{7})$, albatrelin $\mathrm{H}(\mathbf{8})$, were neogrifolin derivatives, $(S)$-10-hydroxygrifolin (9) was a grifolin analogue, and compound $\mathbf{1 2}$ was a violet pigment named albatrellin.

Compound 1, colorless oil, displayed a $[\mathrm{M}]^{+}$ion peak at $m / z 344.2348$ in positive HREIMS, corresponding to the molecular formula $\mathrm{C}_{22} \mathrm{H}_{32} \mathrm{O}_{3}$ and seven degrees of unsaturation. The IR spectrum showed absorption at $3421 \mathrm{~cm}^{-1}$ which indicated the presence of $\mathrm{OH}$ groups. The ${ }^{1} \mathrm{H}$ NMR spectrum contained signals for two $m$-coupling aromatic 


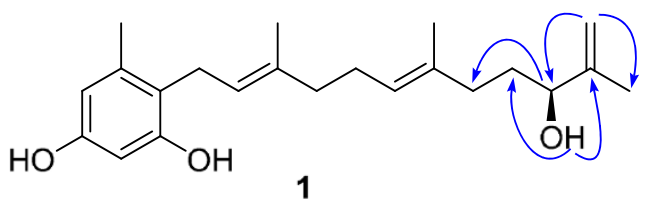<smiles>C/C(=C\Cc1c(C)cc(O)cc1O)CC/C=C(\C)CC[C@@]1(O)CC2CCCC[C@@]1(O)C2</smiles>

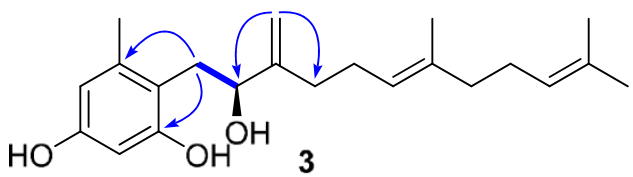

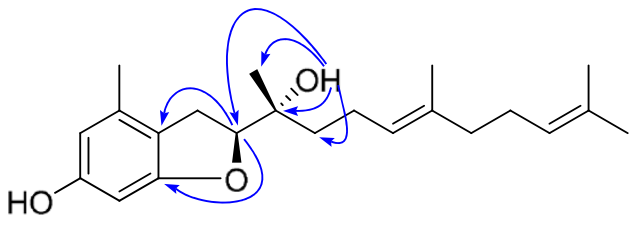

5

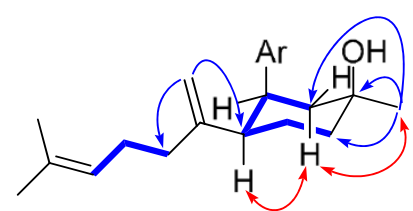

7

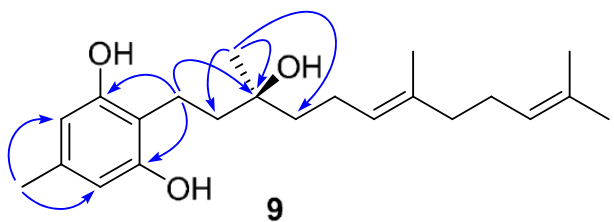

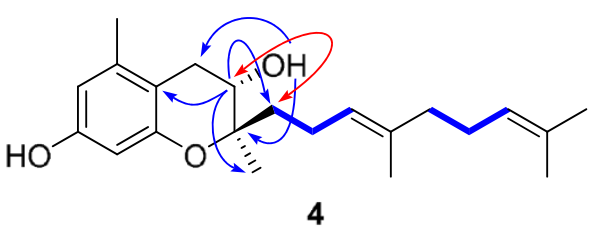

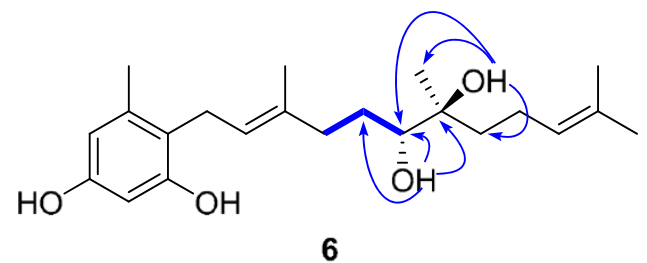

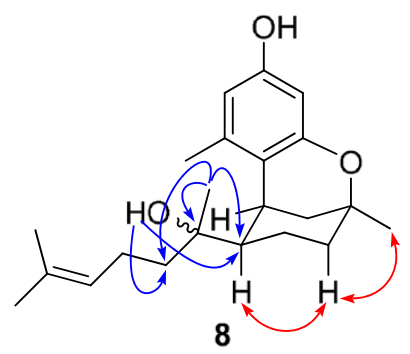

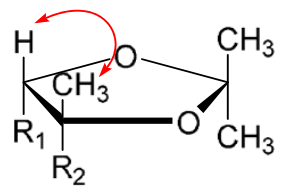

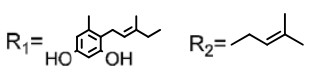

$6 a$

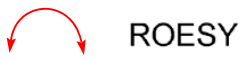

Fig. 2 Selective 2D NMR correlations for compounds 1-9

protons at $\delta_{\mathrm{H}} 6.25(1 \mathrm{H}, \mathrm{d}, J=1.8 \mathrm{~Hz})$ and $6.17(1 \mathrm{H}, \mathrm{d}$, $J=1.8 \mathrm{~Hz}$ ), four olefinic protons, and four singlet methyls. Combined with ${ }^{13} \mathrm{C}$ NMR (DEPT) experiment, the existence of a 1,2,4,6-tetra-substituted phenyl ring, a terminal double bond, two tri-substituted double bonds, one oxygen-bearing methine, five methylenes, and four methyls were assigned. The ${ }^{1} \mathrm{H}$ and ${ }^{13} \mathrm{C}$ NMR spectroscopic data were close to those of neogrifolin, except that a methylene and a methyl group in neogrifolin were replaced by a hydroxyl methine $\left(\delta_{\mathrm{C}} 75.3\right)$ and a terminal double bond $\left(\delta_{\mathrm{C}}\right.$
110.3 and 149.3), respectively. According to the observed HMBC correlations from $\delta_{\mathrm{H}} 6.25$ and $6.17(\mathrm{H}-20)$ to $\delta_{\mathrm{C}}$ 17.8 (C-19) and 75.3 (C-17), the terminal double bond was located at the end of the farnesyl side chain, and the hydroxyl group was at $\mathrm{C}-17\left(\delta_{\mathrm{C}} 75.3\right)$. This conclusion was supported by cross peaks from $\delta_{\mathrm{H}} 3.73(\mathrm{OH}-17)$ to $\delta_{\mathrm{C}} 34.5$ (C-16), 75.3 (C-17) and 149.3 (C-18), and from $3.97(\mathrm{H}-$ 17) to $\delta_{\mathrm{C}} 36.4$ (C-15) in HMBC spectrum (Fig. 2). The absolute configuration of the only chiral center (C-17) of 1 was deduced to be $S$ by comparing the optical rotation 
value of $1\left([\alpha]_{\mathrm{D}}^{21}-9.0, \mathrm{MeOH}\right)$ with that of $(R)-(+)-3$ methyl-3-buten-2-ol $\left([\alpha]_{\mathrm{D}}+7.6, \mathrm{CHCl}_{3}\right)$ [13]. Therefore, compound 1 was elucidated and named as $(S)$-17-hydroxy18,20-ene-neogrifolin.

Compound 2 possessed a molecular formula of $\mathrm{C}_{22} \mathrm{H}_{34} \mathrm{O}_{4}$ according to HREIMS which showed a molecular ion peak at $m / z$ 362.2452, requiring six degrees of unsaturation. Inspection of the ${ }^{1} \mathrm{H}$ and ${ }^{13} \mathrm{C}$ NMR (DEPT) spectra indicated five methyls, five methylenes, four $s p^{2}$ methines, one oxygen-bearing methine, and seven quaternary carbons. The 1D NMR spectroscopic data were similar to those of $\mathbf{1}$, except for the terminal double bond being replaced by a methyl and an oxygen-bearing quaternary carbon, which was confirmed by HMBC correlations from $\delta_{\mathrm{H}} 3.54(\mathrm{OH}-17)$ to $\delta_{\mathrm{C}} 72.9(\mathrm{C}-$ $18)$, from $\delta_{\mathrm{H}} 3.24(\mathrm{H}-17)$ to $\delta_{\mathrm{C}} 25.8(\mathrm{C}-19$ and $\mathrm{C}-20)$, from $\delta_{\mathrm{H}}$ $1.11(\mathrm{H}-20)$ to $\delta_{\mathrm{C}} 25.8(\mathrm{C}-19), 72.9(\mathrm{C}-18)$ and $78.5(\mathrm{C}-17)$. The absolute configuration of $\mathrm{C}-17$ in 2 was assigned to be $S$, the same as $\mathbf{1}$, on a biogenetic point of view. And this supposition was further confirmed by a comparison of the optical rotation values between $2\left([\alpha]_{\mathrm{D}}^{21}-9.2, \mathrm{MeOH}\right)$ and $(R)$-2-methylpentane-2,3-diol $\left([\alpha]_{\mathrm{D}}^{18.5}+27.3\right.$, ether) [14]. Therefore, compound 2 was identified as $(S)-18,19$ dihydroxyneogrifolin.

Compound $\mathbf{3}$ was determined to have the molecular formula of $\mathrm{C}_{22} \mathrm{H}_{32} \mathrm{O}_{3}$ from HREIMS at $\mathrm{m} / z \quad 344.2364$ $\left([\mathrm{M}]^{+}\right)$. The ${ }^{13} \mathrm{C}$ NMR (DEPT) spectra showed signals of a tetra-substituted phenyl moiety, a terminal double bond, two tri-substituted double bonds, a hydroxyl methine, four methyls, and five methylenes, which resembled those of compound 1. Extensive 2D NMR (COSY, ROESY and HMBC) analyses revealed that the locations of the double bond and the oxygen-bearing methine were different with those of 1. COSY correlations from $\delta_{\mathrm{H}} 2.82$ and $2.68(\mathrm{H}-8)$ to $\delta_{\mathrm{H}} 4.28\left(\delta_{\mathrm{C}}=77.0\right)$ suggested that $\mathrm{C}-9$ was the oxygenated carbon. Moreover, $\delta_{\mathrm{H}} 5.11$ and $4.84\left(\delta_{\mathrm{C}}=108.9, \mathrm{t}\right)$ gave $\mathrm{HMBC}$ correlations to $\delta_{\mathrm{C}} 32.5(\mathrm{C}-11)$ and $77.0(\mathrm{C}-9)$, revealing that the Me-22 in compound 1 converted to be a double bond in $\mathbf{3}$. Therefore, the structure of compound $\mathbf{3}$ was identified as 9-hydroxy-10,22-ene-neogrifolin. The absolute stereochemistry of the chiral center of C-9 was determined to be $S$ by comparing the optical rotation value of $3\left([\alpha]_{\mathrm{D}}-8.8, \mathrm{MeOH}\right)$ with $(S)$-3-methyl-1-phenylbutan2-ol $\left([\alpha]_{\mathrm{D}}-29.5, \mathrm{CHCl}_{3}\right)[15]$.

The HREIMS of compound 4 showed a $[\mathrm{M}]^{+}$ion peak at $\mathrm{m} / \mathrm{z}$ 344.2348, indicating a molecular formula of $\mathrm{C}_{22} \mathrm{H}_{32} \mathrm{O}_{3}$ and seven degrees of unsaturation. A comparison of the MS and 1D NMR data of $\mathbf{4}$ with those of $\mathbf{3}$ revealed that $\mathbf{4}$ was another neogrifolin analogue resembled $\mathbf{3}$ except for the double bond between $\mathrm{C}-10$ and $\mathrm{C}-22$ in $\mathbf{3}$ being replaced by a methyl (Me-22) and an oxygenated quaternary carbon $(\mathrm{C}-10)$ in $\mathbf{4}$. This structure requires six degrees of unsaturation, and an additional ring was needed to complete the unsaturation. There were two plausible proposals: an epoxy ring between C-6 and C-9 or between C-6 and C-10. HMBC correlations from $\mathrm{H}-9\left(\delta_{\mathrm{H}} 3.85\right)$ to C-1 $\left(\delta_{\mathrm{C}} 111.0\right), \mathrm{C}-10\left(\delta_{\mathrm{C}} 78.6\right), \mathrm{C}-11\left(\delta_{\mathrm{C}} 38.7\right)$, and C-22 $\left(\delta_{\mathrm{C}} 17.9\right)$, and from the $\mathrm{OH}$ at $\delta_{\mathrm{H}} 4.14$ to $\mathrm{C}-8\left(\delta_{\mathrm{C}} 29.7\right), \mathrm{C}-9$ $\left(\delta_{\mathrm{C}} 68.4\right)$ and $\mathrm{C}-10\left(\delta_{\mathrm{C}} 78.6\right)$ revealed the location of the free $\mathrm{OH}$ at $\mathrm{C}-9$, placing the epoxy ring between $\mathrm{C}-6$ and $\mathrm{C}-10$. Therefore, the planar structure of $\mathbf{4}$ was elucidated as 6,10-epoxy-9-hydroxyneogrifolin. The ROESY spectrum displayed cross peaks of $\mathrm{H}-9 / \mathrm{H}-11$ and $\mathrm{H}-9 / \mathrm{H}-12$, suggesting the same orientation of $\mathrm{H}-9$ and the geranyl group. From a biogenetic point of view, compounds $\mathbf{4}$ and $\mathbf{3}$ should share the same absolute configuration on C-9. So the absolute stereochemistry of compound $\mathbf{4}$ was deduced to be $9 S, 10 R$.

Compound 5 was proposed to be a neogrifolin derivative on basis of HREIMS which displayed the molecular ion peak at $m / z$ 344.2358. A comparison of the ${ }^{13} \mathrm{C} \mathrm{NMR}$ (DEPT) spectra of $\mathbf{5}$ with those of $\mathbf{4}$ revealed the resemblance of the two structures, for example, the presence of the 1-(2-methyl-4,6-dihydroxyl)-phenyl group and the geranyl moiety. The structural difference between compounds 4 and 5 was the fragment from C-8 to C-10, according to the different chemical shifts of the corresponding carbons and protons (Tables 1 and 2). In order to establish the structure of 5, extensive 2D NMR experiments were employed. The HMBC correlations of H-9/C-1 and H-9/C-6 indicated the existence of an oxygen bridge between C-6 and C-9. The free hydroxyl group was determined to be located at $\mathrm{C}-10$ by $\mathrm{HMBC}$ correlations from $\mathrm{OH}-10$ to $\mathrm{C}-9, \mathrm{C}-10, \mathrm{C}-11$ and $\mathrm{C}-22$. Biogenetically speaking, compound $\mathbf{5}$ would show the same stereochemistry at C-9 and C-10 as compound 4. Therefore, compound 5 was elucidated as $(9 S, 10 R)-6,9$-epoxy-10hydroxyneogrifolin.

Compound 6 was obtained as a colorless oil, with a molecular formula of $\mathrm{C}_{22} \mathrm{H}_{34} \mathrm{O}_{4}$ according to the HREIMS at $\mathrm{m} / z 362.2432\left([\mathrm{M}]^{+}\right)$. Inspection of the ${ }^{1} \mathrm{H},{ }^{13} \mathrm{C}$ (DEPT) and HSQC NMR spectra allowed the assignment of five methyls, five methylenes, five methines, seven quaternary carbons, and four active protons. Comparing the ${ }^{1} \mathrm{H}$ and ${ }^{13} \mathrm{C}$ NMR spectroscopic data of 6 with those of neogrifolin indicated that compound 6 shared the "1-(2-methyl-4,6dihydroxyl)-phenyl" partial structure with neogrifolin, but had a different side chain, in which one double bond in the farnesyl group was replaced by two oxygen-bearing $s p^{3}$ carbons. The COSY cross peaks of $\mathrm{H}-11 / \mathrm{H}-12 / \mathrm{H}-13$, and HMBC correlations from $\mathrm{OH}$ at $\delta_{\mathrm{H}} 3.56$ to $\mathrm{C}-12, \mathrm{C}-13$ and $\mathrm{C}-14$, and from $\delta_{\mathrm{H}} 3.20$ to $\mathrm{C}-21, \mathrm{C}-13, \mathrm{C}-14$, and C-15 (Fig. 2) suggested the oxygenated carbons being located at C-13 $\left(\delta_{\mathrm{C}} 77.3, \mathrm{CH}\right)$ and $\mathrm{C}-14\left(\delta_{\mathrm{C}} 74.2, \mathrm{C}\right)$. In order to identify the relative configuration of the two chiral centers C-13 and C-14, compound 6 was reacted with 2,2-dimethoxypropane in DMF for $30 \mathrm{~min}$ at room temperature to 
Table $1{ }^{1} \mathrm{H}$ NMR spectroscopic data for compounds $\mathbf{1 - 6}$ in acetone- $d_{6}(\delta$ in ppm, $J$ in $\mathrm{Hz})$

\begin{tabular}{|c|c|c|c|c|c|c|}
\hline No & $\mathbf{1}^{\mathrm{a}}$ & $2^{\mathrm{c}}$ & $3^{\mathrm{a}}$ & $4^{b}$ & $5^{\mathrm{a}}$ & $6^{\mathrm{c}}$ \\
\hline 3 & $6.17, \mathrm{~d}(1.8)$ & $6.17, \mathrm{~d}(2.3)$ & $6.21, \mathrm{~s}$ & $6.25, \mathrm{~d}(2.1)$ & 6.12 , br. s & $6.17, \mathrm{~s}$ \\
\hline 5 & $6.25, \mathrm{~d}(1.8)$ & $6.25, \mathrm{~d}(2.3)$ & $6.22, \mathrm{~s}$ & $6.12, \mathrm{~d}(2.1)$ & 6.03 , br. s & $6.25, \mathrm{~s}$ \\
\hline 7 & $2.15, \mathrm{~s}$ & $2.15, \mathrm{~s}$ & $2.20, \mathrm{~s}$ & $2.11, \mathrm{~s}$ & $2.11, \mathrm{~s}$ & $2.15, \mathrm{~s}$ \\
\hline 8 & $3.26, \mathrm{~d}(6.7)$ & $3.26, \mathrm{~d}(6.7)$ & $\begin{array}{l}2.82, \text { dd }(14.4,2.2) \\
2.68, \text { dd }(14.4,9.3)\end{array}$ & $\begin{array}{l}2.79, \text { dd }(16.1,5.9) \\
2.45, \text { dd }(16.1,8.5)\end{array}$ & $\begin{array}{l}3.06, \text { dd }(15.3,7.9) \\
2.93 \text {, dd }(15.3,9.5)\end{array}$ & $3.27 *$ \\
\hline 9 & $5.09, \mathrm{t}(6.7)$ & $5.09, \mathrm{t}(6.7)$ & $4.28, \mathrm{dd}(9.3,2.2)$ & $3.85, \operatorname{td}(8.5,5.8)$ & 4.62 , dd $(9.5,7.9)$ & $5.11 *$ \\
\hline 11 & $1.90-2.00, \mathrm{~m}$ & $1.97-1.99, \mathrm{~m}$ & $\begin{array}{l}2.22-2.25 * \\
2.14-2.17, \mathrm{~m}\end{array}$ & $1.66-1.75, \mathrm{~m}$ & $1.50-1.56, \mathrm{~m}$ & $\begin{array}{l}2.25, \mathrm{t}(9.9) \\
1.96-2.03^{*}\end{array}$ \\
\hline 12 & $2.03-2.11, \mathrm{~m}$ & $2.07-2.10, \mathrm{~m}$ & $2.22-2.25^{*}$ & $2.14-2.24, \mathrm{~m}$ & $2.09-2.20, \mathrm{~m}$ & $\begin{array}{l}1.69-1.74, \mathrm{~m} \\
1.33-1.40, \mathrm{~m}\end{array}$ \\
\hline 13 & $5.12, \mathrm{t}(6.6)$ & $5.14, \mathrm{t}(7.0)$ & 5.20 , br. s & $5.17, \mathrm{t}(7.2)$ & $5.18, \mathrm{t}(6.9)$ & $3.29 *$ \\
\hline 15 & $1.90-2.00, \mathrm{~m}$ & $\begin{array}{l}2.21-2.26, \mathrm{~m} \\
1.94-1.97, \mathrm{~m}\end{array}$ & $1.98, \mathrm{t}(7.5)$ & $1.97, \mathrm{t}(7.6)$ & $1.98, \mathrm{t}(7.5)$ & $\begin{array}{l}1.54-1.58, \mathrm{~m} \\
1.33-1.40, \mathrm{~m}\end{array}$ \\
\hline 16 & $1.54-1.58, \mathrm{~m}$ & $\begin{array}{l}1.62-1.68, \mathrm{~m} \\
1.28-1.35, \mathrm{~m}\end{array}$ & $2.07-2.09^{*}$ & $2.06-2.08^{*}$ & $2.06-2.09 *$ & $\begin{array}{l}2.09-2.13, \mathrm{~m} \\
2.03-2.05, \mathrm{~m}\end{array}$ \\
\hline 17 & $3.97, \mathrm{~m}$ & $3.24, \operatorname{td}(5.3,1.8)$ & $5.10^{*}$ & $5.10, \mathrm{t}(6.9)$ & $5.10, \mathrm{t}(7.0)$ & $5.11 * 1$ \\
\hline 19 & $1.68, \mathrm{~s}$ & $1.11, \mathrm{~s}$ & $1.59, \mathrm{~s}$ & $1.58, \mathrm{~s}$ & $1.59, \mathrm{~s}$ & $1.58, \mathrm{~s}$ \\
\hline 20 & $\begin{array}{l}4.89, \text { br. } s \\
4.74, \text { br. } s\end{array}$ & $1.11, \mathrm{~s}$ & $1.65, \mathrm{~s}$ & $1.65, \mathrm{~s}$ & $1.65, \mathrm{~s}$ & $1.64, \mathrm{~s}$ \\
\hline 21 & $1.58, \mathrm{~s}$ & $1.58, \mathrm{~s}$ & $1.63, \mathrm{~s}$ & $1.61, \mathrm{~s}$ & $1.63, \mathrm{~s}$ & $1.07, \mathrm{~s}$ \\
\hline 22 & $1.75, \mathrm{~s}$ & $1.75, \mathrm{~s}$ & $\begin{array}{l}5.11, \text { br. } s \\
4.84, \text { br. } s\end{array}$ & $1.16, \mathrm{~s}$ & $1.20, \mathrm{~s}$ & $1.76, \mathrm{~s}$ \\
\hline 4-ОН & $7.86, \mathrm{~s}$ & $7.88, \mathrm{~s}$ & $8.01, \mathrm{~s}$ & $7.89, \mathrm{~s}$ & $8.05, \mathrm{~s}$ & $7.89, \mathrm{~s}$ \\
\hline 6-OH & $8.02, \mathrm{~s}$ & $8.06, \mathrm{~s}$ & $8.56, \mathrm{~s}$ & & & $8.05, \mathrm{~s}$ \\
\hline 9-ОH & & & $4.88, \mathrm{~d}(2.8)$ & $4.14, \mathrm{~d}(5.6)$ & & \\
\hline 10-OH & & & & & $3.54, \mathrm{~s}$ & \\
\hline 13-OH & & & & & & $3.56, \mathrm{~d}(5.8)$ \\
\hline 14-OH & & & & & & $3.20, \mathrm{~s}$ \\
\hline 17-OH & $3.73, \mathrm{~d}(4.2)$ & $3.54, \mathrm{~d}(5.3)$ & & & & \\
\hline 18-OH & & $3.40, \mathrm{~s}$ & & & & \\
\hline
\end{tabular}

${ }^{a}$ Measured at $400 \mathrm{MHz}$

b Measured at $500 \mathrm{MHz}$

c Measured at $600 \mathrm{MHz}$

* Signals were overlapped

yield its di-O-isopropylidene derivative 6a. The observed ROESY correlations of Me-21/H-13 (Fig. 2) indicated that the 13,14-diol existed as the erythro form. So, the absolute configuration of $\mathbf{6}$ should be $13 S, 14 S$ or $13 R, 14 R$.

Compound 7 possessed a molecular formula of $\mathrm{C}_{22} \mathrm{H}_{32} \mathrm{O}_{3}$ from its HREIMS, which displayed a molecular ion peak at $\mathrm{m} / \mathrm{z}$ 344.2348. A comparison of the ${ }^{1} \mathrm{H}$ and ${ }^{13} \mathrm{C}$ NMR data of $\mathbf{7}$ with those of $\mathbf{1}$ revealed the presence of the 1-(2-methyl-4,6-dihydroxyl)-phenyl group. Combined with MS spectral data, compound 7 was determined to be a neogrifolin derivative unambiguously. Unlike the other neogrifolin analogues (1-6) which had straight-chains as "tails", compound 7 had a cyclohexane moiety—by C-8 connecting to $\mathrm{C}-13$ - in its tail. It was supported by COSY correlations of $\mathrm{H}-9 / \mathrm{H}-8 / \mathrm{H}-13 / \mathrm{H}-12 / \mathrm{H}-11$, and HMBC cross peaks from Me-22 to C-9, C-10 and C-11 (Fig. 2). The remaining part of the "tail" was a 2-(6-methyl)-1,5-heptadiene residue. This residue was connected with $\mathrm{C}-13$, because COSY correlations of $\mathrm{H}-15 / \mathrm{H}-16 / \mathrm{H}-17$, and HMBC correlations from $\mathrm{H}-21$ to $\mathrm{C}-13$ and $\mathrm{C}-15$, and from Me-19 and -20 to C-18 and C-17 (Fig. 2) were observed. In order to determine the relative stereochemistry of $\mathrm{C}-8$, $\mathrm{C}-10$ and $\mathrm{C}-13$, a ROESY experiment was performed, combined with further analysis of the coupling constants of several signals in ${ }^{1} \mathrm{H}$ NMR spectrum. The observed broad singlet (br. s) signal of $\mathrm{H}-8\left(\delta_{\mathrm{H}}=3.22\right)$ in its ${ }^{1} \mathrm{H}$ NMR 
spectrum indicated that $\mathrm{H}-8$ existed as an equatorial bond in the stable boat conformation of the cyclohexane moiety, as shown in Fig. 2. Likewise, H-13 was proposed to be in an axial position because of the doublet of triplets at $\delta_{\mathrm{H}}$ 3.22 with coupling constants of 12.5 and $2.7 \mathrm{~Hz}$, respectively. Furthermore, The ROESY correlations of $\mathrm{H}-13 / \mathrm{H}_{\mathrm{ax}^{-}}$ 9 and $\mathrm{Me}-22 / \mathrm{H}_{\mathrm{ax}}-9$ revealed the same orientation of $\mathrm{H}-13$ and Me-22. Therefore, H-8, H-13 and Me-22 were deduced to be $\alpha-\alpha-\alpha$ - orientated. In compound 7 , a ring was formed by new $\mathrm{C}-\mathrm{C}$ bond connection between $\mathrm{C}-8$ and $\mathrm{C}-13$ in side chain.

Compound 8 exhibited a molecular ion peak at $\mathrm{m} / \mathrm{z}$ 344.2345 in HREIMS, indicating the molecular formula of $\mathrm{C}_{22} \mathrm{H}_{32} \mathrm{O}_{3}$ which required seven degrees of unsaturation. According to the ${ }^{1} \mathrm{H}$ and ${ }^{13} \mathrm{C}$ NMR (DEPT) spectra, 22 carbon signals were recognized as five methyls, four methylenes, five methines, and seven quaternary carbons. Extensive NMR analyses suggested that the structure of $\mathbf{8}$ resembled that of 7 , except for the terminal double bond C-14=C-21 in 7 being saturated to be a methyl and an oxygen-bearing quaternary carbon, which was confirmed by HMBC correlations from $\delta_{\mathrm{H}} 1.13(\mathrm{Me}-21)$ to $\delta_{\mathrm{C}} 36.8$
(C-15), 55.9 (C-13), and $74.0(\mathrm{C}-14)$, and from $\delta_{\mathrm{H}} 3.30$ (OH-14) to $\delta_{\mathrm{C}} 36.8(\mathrm{C}-15), 55.9(\mathrm{C}-13)$, and $74.0(\mathrm{C}-14)$. So far, six degrees of unsaturation was assigned, and one more ring should be constructed to complete the structure of 8. The only possible ring to be formed was the oxygen bridge between C- 6 and C-10. The stereochemistry of C-13 was identified by analysis of ${ }^{1} \mathrm{H}$ NMR spectrum, in which H-13 showed a doublet-of-triplets peak with the coupling constants of 12.8 and $2.0 \mathrm{~Hz}$, respectively, suggesting the axial bond of H-13. Me-22 had the same orientation as $\mathrm{H}-13$ by the observed ROESY correlations of $\mathrm{H}-13 / \mathrm{H}_{\mathrm{ax}}-11 /$ $\mathrm{Me}-22$, and because of the planar structure of the phenyl group, $\mathrm{H}-8$ and Me-22 should be on the same orientation. Thus, H-8, H-13 and Me-22 were determined to be $\alpha-, \alpha$, $\alpha$ - orientated, the same as for compound 7 .

Compound 9 was proposed to possess a molecular formula of $\mathrm{C}_{22} \mathrm{H}_{34} \mathrm{O}_{3}$ on basis of HREIMS at $\mathrm{m} / \mathrm{z}, 346.2505$ $\left([\mathrm{M}]^{+}\right)$. Its ${ }^{13} \mathrm{C}$ NMR (DEPT) spectrum showed 20 carbon signals, including two signals at $\delta_{\mathrm{C}} 108.4(\mathrm{CH})$ and 156.7 (C) which represented two carbons respectively. The overlapped carbon signals indicated that $\mathbf{9}$ was a grifolin derivative possessing a symmetric aromatic ring, which

Table $2{ }^{13} \mathrm{C}$ NMR spectroscopic data for compounds $\mathbf{1 - 6}$ in acetone- $d_{6}(\delta$ in ppm)

\begin{tabular}{|c|c|c|c|c|c|c|}
\hline No & $1^{\mathrm{a}}$ & $2^{c}$ & $3^{\mathrm{a}}$ & $4^{b}$ & $5^{\mathrm{a}}$ & $6^{c}$ \\
\hline 1 & 118.3, C & $118.3, \mathrm{C}$ & 117.1, C & $111.0, \mathrm{C}$ & 117.8, C & $118.3, \mathrm{C}$ \\
\hline 2 & $138.9, \mathrm{C}$ & $138.9, \mathrm{C}$ & $139.0, \mathrm{C}$ & 138.6, C & $135.2, \mathrm{C}$ & $138.8, \mathrm{C}$ \\
\hline 3 & $109.4, \mathrm{CH}$ & $109.3, \mathrm{CH}$ & $109.8, \mathrm{CH}$ & $110.1, \mathrm{CH}$ & $108.5, \mathrm{CH}$ & $109.3, \mathrm{CH}$ \\
\hline 4 & $156.5, \mathrm{C}$ & $156.5, \mathrm{C}$ & 157.1, C & 157.1, C & $158.4, \mathrm{C}$ & $156.5, \mathrm{C}$ \\
\hline 5 & $101.0, \mathrm{CH}$ & $101.0, \mathrm{CH}$ & $102.2, \mathrm{CH}$ & $102.0, \mathrm{CH}$ & $95.2, \mathrm{CH}$ & $101.0, \mathrm{CH}$ \\
\hline 6 & $156.4, \mathrm{C}$ & $156.4, \mathrm{C}$ & $157.9, \mathrm{C}$ & 154.7, C & 161.6, C & $156.4, \mathrm{C}$ \\
\hline 7 & $19.9, \mathrm{CH}_{3}$ & $19.9, \mathrm{CH}_{3}$ & $20.5, \mathrm{CH}_{3}$ & $19.3, \mathrm{CH}_{3}$ & $19.0, \mathrm{CH}_{3}$ & $19.9, \mathrm{CH}_{3}$ \\
\hline 8 & $25.1, \mathrm{CH}_{2}$ & $25.1, \mathrm{CH}_{2}$ & $34.4, \mathrm{CH}_{2}$ & 29.7, $\mathrm{CH}_{2}$ & $29.1, \mathrm{CH}_{2}$ & $25.1, \mathrm{CH}_{2}$ \\
\hline 9 & $124.8, \mathrm{CH}$ & $124.8, \mathrm{CH}$ & $77.0, \mathrm{CH}$ & $68.4, \mathrm{CH}$ & $89.8, \mathrm{CH}$ & $124.4, \mathrm{CH}$ \\
\hline 10 & $134.1, \mathrm{C}$ & 134.1, C & $153.4, \mathrm{C}$ & 78.6, C & $73.3, \mathrm{C}$ & 134.6, C \\
\hline 11 & $40.4, \mathrm{CH}_{2}$ & $40.4, \mathrm{CH}_{2}$ & $32.5, \mathrm{CH}_{2}$ & $38.7, \mathrm{CH}_{2}$ & $39.3, \mathrm{CH}_{2}$ & $37.8, \mathrm{CH}_{2}$ \\
\hline 12 & $27.2, \mathrm{CH}_{2}$ & $27.2, \mathrm{CH}_{2}$ & 27.3, $\mathrm{CH}_{2}$ & $22.1, \mathrm{CH}_{2}$ & $22.5, \mathrm{CH}_{2}$ & $30.2, \mathrm{CH}_{2}$ \\
\hline 13 & $124.8, \mathrm{CH}$ & $124.8, \mathrm{CH}$ & $125.1, \mathrm{CH}$ & $125.4, \mathrm{CH}$ & 125.6, CH & $77.8, \mathrm{CH}$ \\
\hline 14 & $135.5, \mathrm{C}$ & $135.8, \mathrm{C}$ & 135.7, C & $135.4, \mathrm{C}$ & $135.3, \mathrm{C}$ & $74.2, \mathrm{C}$ \\
\hline 15 & $36.4, \mathrm{CH}_{2}$ & 37.6, $\mathrm{CH}_{2}$ & $40.4, \mathrm{CH}_{2}$ & $40.4, \mathrm{CH}_{2}$ & $40.4, \mathrm{CH}_{2}$ & $38.5, \mathrm{CH}_{2}$ \\
\hline 16 & $34.5, \mathrm{CH}_{2}$ & $30.7, \mathrm{CH}_{2}$ & 27.3, $\mathrm{CH}_{2}$ & $27.4, \mathrm{CH}_{2}$ & $27.3, \mathrm{CH}_{2}$ & 22.6, $\mathrm{CH}_{2}$ \\
\hline 17 & $75.3, \mathrm{CH}$ & $78.5, \mathrm{CH}$ & $125.1, \mathrm{CH}$ & $125.1, \mathrm{CH}$ & $125.1, \mathrm{CH}$ & $126.2, \mathrm{CH}$ \\
\hline 18 & $149.3, \mathrm{C}$ & $72.9, \mathrm{C}$ & 131.6, C & $131.6, \mathrm{C}$ & $131.6, \mathrm{C}$ & 131.1, C \\
\hline 19 & $17.8, \mathrm{CH}_{3}$ & $25.8, \mathrm{CH}_{3}$ & $17.7, \mathrm{CH}_{3}$ & $17.7, \mathrm{CH}_{3}$ & $17.7, \mathrm{CH}_{3}$ & 17.6, $\mathrm{CH}_{3}$ \\
\hline 20 & $110.3, \mathrm{CH}_{2}$ & $25.8, \mathrm{CH}_{3}$ & $25.8, \mathrm{CH}_{3}$ & $25.8, \mathrm{CH}_{3}$ & $25.8, \mathrm{CH}_{3}$ & $25.8, \mathrm{CH}_{3}$ \\
\hline 21 & $16.1, \mathrm{CH}_{3}$ & $16.1, \mathrm{CH}_{3}$ & $16.1, \mathrm{CH}_{3}$ & $16.0, \mathrm{CH}_{3}$ & $16.0, \mathrm{CH}_{3}$ & $22.8, \mathrm{CH}_{3}$ \\
\hline 22 & $16.1, \mathrm{CH}_{3}$ & $16.1, \mathrm{CH}_{3}$ & $108.9, \mathrm{CH}_{2}$ & $17.9, \mathrm{CH}_{3}$ & $22.3, \mathrm{CH}_{3}$ & 16.3, $\mathrm{CH}_{3}$ \\
\hline
\end{tabular}

\footnotetext{
${ }^{a}$ Measured at $100 \mathrm{MHz}$

b Measured at $125 \mathrm{MHz}$

c Measured at $150 \mathrm{MHz}$
} 
was confirmed by HMBC cross peaks from $\delta_{\mathrm{H}} 2.10$ (Me-7) to $\delta_{\mathrm{C}} 108.4(\mathrm{C}-3$ and -5$)$ and $136.5(\mathrm{C}-4)$, from $\delta_{\mathrm{H}} 2.67(\mathrm{H}-$ $8)$ to $\delta_{\mathrm{C}} 113.9(\mathrm{C}-1)$ and $156.7(\mathrm{C}-2$ and -6$)$, and from $\delta_{\mathrm{H}}$ $8.05(\mathrm{OH}-2$ and -6$)$ to $\delta_{\mathrm{C}} 108.4(\mathrm{C}-3$ and -5$), 113.9(\mathrm{C}-1)$ and 156.7 (C-2 and -6$)$. Besides the aromatic ring, the remaining signals represented an oxygenated farnesyl group with four methyls, six methylenes, two pairs of trisubstituted double bonds, and one oxygenated quaternary carbon. The next problem to be resolved was the position of oxygenation, which was addressed by 2D NMR (HMBC and COSY) experiments. The HMBC correlations from $\delta_{\mathrm{H}}$ $2.67(\mathrm{H}-8)$ to $\delta_{\mathrm{C}} 72.6(\mathrm{C}-10)$, and from $\delta_{\mathrm{H}} 1.20(\mathrm{Me}-22)$ to $\delta_{\mathrm{C}} 41.2(\mathrm{C}-9), 72.6(\mathrm{C}-10)$ and $42.6(\mathrm{C}-11)$ revealed the hydroxylation of C-10. Hence, the planar structure of 9 was established as 10-hydroxygrifolin. The absolute stereochemistry of C-10 was deduced to be $S$ by a comparison of the optical rotation value of $\mathbf{9}\left([\alpha]_{\mathrm{D}}-8.7, \mathrm{MeOH}\right)$ with that of (S)-3-methyl-1-phenyl-3-pentanol $\left([\alpha]_{\mathrm{D}}-1.6, \mathrm{CHCl}_{3}\right)$ [16].

All the new compounds were assayed for their cytotoxicity against five human cancer cell lines (HL-60, SMMC-7712, A-549, MCF-7, and SW480) by the MTT method in vitro, with DDP and taxol as positive controls. Compound 7 showed cytotoxic activities to cell lines HL60, SMMC-7721, A-549, and MCF-7, with $\mathrm{IC}_{50}$ of 12.8 , 33.8, 33.0, and $33.2 \mu \mathrm{M}$, respectively, and $\mathbf{8}$ exhibited weak growth inhibition activity to human tumor cell lines HL-60 and A-549, with $\mathrm{IC}_{50}$ of 21.8 and $30.3 \mu \mathrm{M}$, respectively.

\section{Experimental Section}

\subsection{General Experimental Procedures}

Optical rotations were measured on a Jasco model 1020 polarimeter (Jasco International Co. Ltd, Tokyo, Japan). UV spectra were recorded on a Shimadzu double-beam 2401A spectrophotometer (Shimadzu, Kyoto, Japan). IR spectra were obtained on a Bruker Tensor 27 FT-IR spectrometer (Bruker, Ettlingen, Germany) using $\mathrm{KBr}$ pellets. 1D and 2D NMR spectra were acquired on Bruker AV-600, DRX-500 and AM-400 instruments at room temperature with TMS as internal standard (Bruker, Rheinstetten, Germany). Chemical shifts $(\delta)$ were expressed in ppm with reference to the solvent signals. Mass spectra (MS) were recorded on a VG Autospec-3000 spectrometer (VG, Manchester, England). Silica gel (200-300 mesh, Qingdao Marine Chemical Inc., Qingdao, China), Sephadex LH-20 (Amersham Biosciences, Sweden), and RP-18 gel (40-75 $\mu \mathrm{m}$, Fuji Silysia Chemical Ltd. Japan) were used for CC. HPLC analysis (Zorbax SB-C18, $5 \mu \mathrm{m}, 4.6 \times 150 \mathrm{~mm}$ ) was performed on an Agilent 1100 liquid chromatography system, and semi-preparative HPLC was performed on an Agilent 1200 liquid chromatography system equipped with a Zorbax SB- $\mathrm{C}_{18}$ column $(9.4 \mathrm{~mm} \times 150 \mathrm{~mm})$. Pre-coated silica gel GF254 plates (Qingdao Marine Chemical Inc., Qingdao, China) were used for TLC. Fractions were monitored by TLC, and spots were visualized by heating silica gel plates sprayed with $10 \% \mathrm{H}_{2} \mathrm{SO}_{4}$ in ethanol.

\subsection{Fungal Material}

The fungus A. caeruleoporus was collected in Anhui province, China, in October, 2011. The voucher specimen (GDGM 29146) has been deposited in the Herbarium of Microbiology Institute of Guangdong.

\subsection{Extraction and Isolation}

The dried fruiting bodies of A. caeruleoporus (about $200 \mathrm{~g}$ ) were extracted with chloroform/methanol (1/1) for three times $(5 \mathrm{~L} \times 3)$. Evaporation of the solvent under reduced pressure gave the crude extract $(20 \mathrm{~g})$, which was subjected to silica gel $\mathrm{CC}$ using a petroleum ether-acetone gradient $(1: 0 \rightarrow 0: 1)$ to afford fractions A-E. Fraction B was purified by $\mathrm{CC}$ over silica gel with a petroleum etheracetone system $(20: 1 \rightarrow 10: 1)$ to yield two fractions $B_{1}$ and $B_{2}$. Fraction $B_{1}$ was purified by semi-preparative HPLC $\left(\mathrm{CH}_{3} \mathrm{CN} / \mathrm{H}_{2} \mathrm{O}, 6: 4\right)$ to gave $\mathbf{1}(5.2 \mathrm{mg})$ and $\mathbf{1 0}$ $\left(12.0 \mathrm{mg}\right.$ ), while $\mathrm{B}_{2}$ was applied on a Sephadex LH-20 $\left(\mathrm{CHCl}_{3} / \mathrm{MeOH} 1 / 1\right)$ column and then on semi-preparative HPLC eluting with $\mathrm{MeCN}-\mathrm{H}_{2} \mathrm{O}$ (6:4) to yield compounds 2 $(6.0 \mathrm{mg})$ and $\mathbf{1 1}(21.0 \mathrm{mg})$. Fraction $\mathrm{C}$ was subjected to CC with RP-18 silica gel eluting with $90 \%$ methanol, and then purified by semi-preparative HPLC $\left(\mathrm{CH}_{3} \mathrm{CN} / \mathrm{H}_{2} \mathrm{O}, 55: 45\right)$ to get compound $6(5.1 \mathrm{mg})$. Fraction $\mathrm{D}$ was submitted to silica gel CC eluting with petroleum ether-acetone gradient (15:1) to gave two fractions $\mathrm{D}_{1}$ and $\mathrm{D}_{2}$, which were purified first by PR-18 and then by Sephadex LH-20 CC to yield fractions $\mathrm{D}_{1}{ }^{\prime}$ and $\mathrm{D}_{2}{ }^{\prime}$, respectively. Fraction $\mathrm{D}_{1}{ }^{\prime}$ was loaded on a semi-preparative HPLC eluting with $\mathrm{MeCN}$ $\mathrm{H}_{2} \mathrm{O}(60: 40 \rightarrow 65: 35)$ to afford compounds $9(4.8 \mathrm{mg})$ and $3(4.5 \mathrm{mg})$, while fraction $\mathrm{D}_{2}{ }^{\prime}$ was passed through a semipreparative HPLC $\left(\mathrm{MeCN} / \mathrm{H}_{2} \mathrm{O}, 60: 40 \rightarrow 65: 35\right)$ to yield compounds $8(6.4 \mathrm{mg})$ and $\mathbf{5}(4.0 \mathrm{mg})$. Fraction $\mathrm{E}$ was applied on CC over RP-18 to give fractions $E_{1}$ and $E_{2}$. Compound $4(6.5 \mathrm{mg})$ was obtained from fraction $\mathrm{E}_{1}$ which was passed through silica gel column (petroleum ether-acetone, 10:1), Sephadex LH-20 column (chloroform-methanol, 1:1), and semi-preparative HPLC (MeCN/ $\mathrm{H}_{2} \mathrm{O}$ 7:3), successively. Fraction $\mathrm{E}_{2}$ was passed through Sephadex LH-20, and then loaded on semi-preparative HPLC to yield compound 7 (4.5 mg). 


\section{4 (S)-17-hydroxy-18,20-ene-neogrifolin (1)}

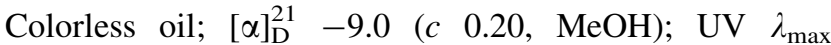
$(\mathrm{MeOH})(\log \varepsilon) 283$ (2.67) nm; IR (KBr) $v_{\max } 3421,3075$, 2970, 2922, 2855, 1611, 1447, $1140 \mathrm{~cm}^{-1}$; ${ }^{1} \mathrm{H}$ and ${ }^{13} \mathrm{C}$ NMR spectroscopic data, see Tables 1 and 2; EI-MS $\mathrm{m} / \mathrm{z}$ : $344[\mathrm{M}]^{+}, 326\left[\mathrm{M}-\mathrm{H}_{2} \mathrm{O}\right]^{+}, 191,175,137$; HR-EI-MS m/z: $344.2348[\mathrm{M}]^{+}$(calcd for $\mathrm{C}_{22} \mathrm{H}_{32} \mathrm{O}_{3}, 344.2351$ ).

\section{5 (S)-18,19-dihydroxyneogrifolin (2)}

Colorless oil; $[\alpha]_{\mathrm{D}}^{21}-9.2(c \quad 0.18, \mathrm{MeOH}) ; \mathrm{UV} \lambda_{\max }$ $(\mathrm{MeOH})(\log \varepsilon) 282$ (2.67) nm; IR (KBr) $v_{\max } 3423,2974$, 2925, 2855, 1613,1467, $1141 \mathrm{~cm}^{-1} ;{ }^{1} \mathrm{H}$ and ${ }^{13} \mathrm{C}$ NMR spectroscopic data, see Tables 1 and 2; EI-MS m/z: 363 $[\mathrm{M}+\mathrm{H}]^{+}, 362[\mathrm{M}]^{+}, 344\left[\mathrm{M}-\mathrm{H}_{2} \mathrm{O}\right]^{+}, 191,175,137$; HREI-MS $m / z: 362.2452[\mathrm{M}]^{+}$(calcd for $\mathrm{C}_{22} \mathrm{H}_{34} \mathrm{O}_{4}$, 362.2457).

\section{6 (S)-9-hydroxy-10,22-ene-neogrifolin (3)}

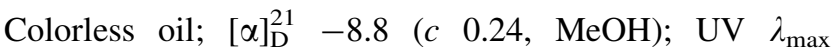
$(\mathrm{MeOH})(\log \varepsilon) 283$ (2.90) nm; IR (KBr) $v_{\max } 3420,2966$, 2923, 2855, 1614, 1447, $1143 \mathrm{~cm}^{-1} ;{ }^{1} \mathrm{H}$ and ${ }^{13} \mathrm{C}$ NMR spectroscopic data, see Tables 1 and 2; EI-MS $\mathrm{m} / z$ : 344 $[\mathrm{M}]^{+}, 326\left[\mathrm{M}-\mathrm{H}_{2} \mathrm{O}\right]^{+}, 137$; HR-EI-MS $m / z: 344.2364$ $[\mathrm{M}]^{+}$(calcd for $\mathrm{C}_{22} \mathrm{H}_{32} \mathrm{O}_{3}, 344.2351$ ).

\section{$3.7(9 S, 10 R)$-6,10-epoxy-9-hydroxyneogrifolin (4)}

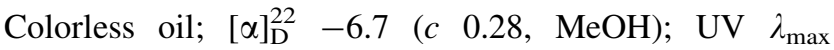
$(\mathrm{MeOH})(\log \varepsilon) 282(2.74) \mathrm{nm}$; IR (KBr) $v_{\max } 3422,3038$, 2967, 2923, 2854, 1618, 1601, 1460, $1138 \mathrm{~cm}^{-1} ;{ }^{1} \mathrm{H}$ and ${ }^{13} \mathrm{C}$ NMR spectroscopic data, see Tables 1 and 2; EI-MS $\mathrm{m} / \mathrm{z}: 344[\mathrm{M}]^{+}, 191,137$; HR-EI-MS $\mathrm{m} / z: 344.2348[\mathrm{M}]^{+}$ (calcd for $\mathrm{C}_{22} \mathrm{H}_{32} \mathrm{O}_{3}, 344.2351$ ).

\section{$3.8(9 S, 10 R)$-6,9-epoxy-10-hydroxyneogrifolin (5)}

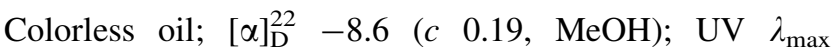
$(\mathrm{MeOH})(\log \varepsilon) 282(2.82) \mathrm{nm}$; IR (KBr) $v_{\max } 3513,3405$, 2969, 2922, 2856, 1629, 1602, 1495, 1449, $1128 \mathrm{~cm}^{-1} ;{ }^{1} \mathrm{H}$ and ${ }^{13} \mathrm{C}$ NMR spectroscopic data, see Tables 1 and 2; EIMS $m / z: 344[\mathrm{M}]^{+}, 191,175,150$; HR-EI-MS $m / z$ : $344.2358[\mathrm{M}]^{+}$(calcd for $\mathrm{C}_{22} \mathrm{H}_{32} \mathrm{O}_{3}, 344.2351$ ).

\section{9 (-)-13,14-Dihydroxyneogrifolin (6)}

Colorless oil; $[\alpha]_{\mathrm{D}}^{22}-9.2(c \quad 0.20, \mathrm{MeOH}) ; \mathrm{UV} \lambda_{\max }$ $(\mathrm{MeOH})(\log \varepsilon) 282$ (2.65) nm; IR (KBr) $v_{\max } 3440,2969$, 2924, 2856, 1628, 1452, $1141 \mathrm{~cm}^{-1} ;{ }^{1} \mathrm{H}$ and ${ }^{13} \mathrm{C}$ NMR spectroscopic data, see Tables 1 and 2; EI-MS m/z: 362 $[\mathrm{M}]^{+}, 344\left[\mathrm{M}-\mathrm{H}_{2} \mathrm{O}\right]^{+}, 326\left[\mathrm{M}-2 \times \mathrm{H}_{2} \mathrm{O}\right]^{+}, 191,175,137$;
HR-EI-MS $m / z: 362.2432[\mathrm{M}]^{+}$(calcd for $\mathrm{C}_{22} \mathrm{H}_{34} \mathrm{O}_{4}$, 362.2457).

\subsection{Albatrelin G (7)}

Colorless oil; $[\alpha]_{\mathrm{D}}^{22}-15.2(c \quad 0.19, \mathrm{MeOH}) ; \mathrm{UV} \lambda_{\max }$ $(\mathrm{MeOH})(\log \varepsilon) 283$ (2.93) nm; IR (KBr) $v_{\max } 3441,2969$, 2929, 2855, 1640,1615, 1495, 1452, $1141 \mathrm{~cm}^{-1} ;{ }^{1} \mathrm{H}$ and ${ }^{13} \mathrm{C}$ NMR spectroscopic data, see Table 3; EI-MS $m / z: 344$ $[\mathrm{M}]^{+}, 326\left[\mathrm{M}-\mathrm{H}_{2} \mathrm{O}\right]^{+}, 175$; HR-EI-MS $\mathrm{m} / \mathrm{z}: 344.2348$ $[\mathrm{M}]^{+}$(calcd for $\mathrm{C}_{22} \mathrm{H}_{32} \mathrm{O}_{3}, 344.2351$ ).

\subsection{Albatrelin H (8)}

Colorless oil; $[\alpha]_{\mathrm{D}}^{22}-9.1(c \quad 0.21, \mathrm{MeOH}) ; \quad \mathrm{UV} \lambda_{\max }$ $(\mathrm{MeOH})(\log \varepsilon) 284(2.63) \mathrm{nm}$; IR (KBr) $v_{\max } 3441,2968$, 2929, 2872, 2855, 1615, 1595, 1452, $1145 \mathrm{~cm}^{-1} ;{ }^{1} \mathrm{H}$ and ${ }^{13} \mathrm{C}$ NMR spectroscopic data, see Table 3; EI-MS m/z: 344 $[\mathrm{M}]^{+}, 175,137$; HR-EI-MS $m / z: 344.2345[\mathrm{M}]^{+}$(calcd for $\mathrm{C}_{22} \mathrm{H}_{32} \mathrm{O}_{3}, 344.2351$ ).

\subsection{2 (S)-10-hydroxygrifolin (9)}

Colorless oil; $[\alpha]_{\mathrm{D}}^{22}-8.7(c \quad 0.20, \mathrm{MeOH}) ; \quad \mathrm{UV} \quad \lambda_{\max }$ $(\mathrm{MeOH})(\log \varepsilon) 276(2.50) \mathrm{nm}$; IR (KBr) $v_{\max } 3441,2967$, 2925, 2856, 1628, 1598, 1452, 1381, $1050 \mathrm{~cm}^{-1} ;{ }^{1} \mathrm{H}$ and ${ }^{13} \mathrm{C}$ NMR spectroscopic data, see Table 3; EI-MS $\mathrm{m} / \mathrm{z}: 346$ $[\mathrm{M}]^{+}, 328\left[\mathrm{M}-\mathrm{H}_{2} \mathrm{O}\right]^{+}, 175,137$; HR-EI-MS m/z: 346.2505 $[\mathrm{M}]^{+}$(calcd for $\mathrm{C}_{22} \mathrm{H}_{34} \mathrm{O}_{3}, 346.2508$ ).

\subsection{Preparation of $\mathbf{6 a}$}

To a solution of compound 6 (2.3 mg, $6.35 \mu \mathrm{mol})$ in DMF $(2 \mathrm{~mL})$ were added 2,2-dimethoxypropane $(1.3 \mathrm{mg}$, $12.7 \mu \mathrm{mol}$ ) and $p$-toluenesulfonic acid monohydrate (0.6 $\mathrm{mg}, 3.18 \mu \mathrm{mol})$, and the mixture was stirred for $30 \mathrm{~min}$ at room temperature. The reaction mixture was added into water, and then extracted by EtOAc for three times. The organic layer was evaporated and the residue was chromatographed on a column of silica gel eluting with petroleum ether-acetone 40:1 to yield $6 \mathbf{6}(2.1 \mathrm{mg})$.

\subsection{Cytotoxic assay}

The following human tumor cell lines were used: HL-60, SMMC-7712, A-549, MCF-7, and SW480. All the cells were cultured in RMPI-1640 or DMEM medium (Hyclone, Logan, UT), supplemented with $10 \%$ fetal bovine serum (Hyclone) at $37{ }^{\circ} \mathrm{C}$ in a humidified atmosphere with $5 \%$ $\mathrm{CO}_{2}$. Cell viability was assessed by conducting colorimetric measurements of the amount of insoluble formazan formed in living cells based on the reduction of 3-(4,5dimethylthiazol-2-yl)-2,5-diphenyltetrazolium bromide 
Table $3{ }^{1} \mathrm{H}$ and ${ }^{13} \mathrm{C}$ NMR spectroscopic data for compounds 7-9 in acetone- $d_{6}(\delta$ in ppm, $J$ in $\mathrm{Hz})$

\begin{tabular}{|c|c|c|c|c|c|c|}
\hline \multirow[t]{2}{*}{ No } & \multicolumn{2}{|l|}{$7^{\mathrm{b}}$} & \multicolumn{2}{|l|}{$8^{\mathrm{a}}$} & \multicolumn{2}{|l|}{$9^{a}$} \\
\hline & $\delta_{\mathrm{C}}$, type & $\delta_{\mathrm{H}}(J$ in $\mathrm{Hz})$ & $\delta_{\mathrm{C}}$, type & $\delta_{\mathrm{H}}(J$ in $\mathrm{Hz})$ & $\delta_{\mathrm{C}}$, type & $\delta_{\mathrm{H}}(J$ in $\mathrm{Hz})$ \\
\hline 1 & $113.7, \mathrm{C}$ & & $115.6, \mathrm{C}$ & & $113.9, \mathrm{C}$ & \\
\hline 2 & 139.1, C & & 139.1, C & & 156.7, C & \\
\hline 3 & $109.3, \mathrm{CH}$ & $6.11, \mathrm{~d}(2.3)$ & 109.6, CH & $6.13, \mathrm{~d}(2.2)$ & $108.4, \mathrm{CH}$ & $6.19, \mathrm{~s}$ \\
\hline 4 & 157.0, C & & 157.0, C & & $136.5, \mathrm{C}$ & \\
\hline 5 & $100.6, \mathrm{CH}$ & $6.09, \mathrm{~d}(2.3)$ & $100.7, \mathrm{CH}$ & $6.07, \mathrm{~d}(2.2)$ & $108.4, \mathrm{CH}$ & $6.19, \mathrm{~s}$ \\
\hline 6 & $158.6, \mathrm{C}$ & & $158.6, \mathrm{C}$ & & $156.7, \mathrm{C}$ & \\
\hline 7 & $20.0, \mathrm{CH}_{3}$ & $2.01, \mathrm{~s}$ & $20.9, \mathrm{CH}_{3}$ & $2.36, \mathrm{~s}$ & $21.2, \mathrm{CH}_{3}$ & $2.10, \mathrm{~s}$ \\
\hline 8 & $33.9, \mathrm{CH}$ & 3.22 , br. s & $30.3, \mathrm{CH}$ & 3.52 , br. $\mathrm{s}$ & $18.2, \mathrm{CH}_{2}$ & $2.67, \mathrm{~m}$ \\
\hline 9 & $38.9, \mathrm{CH}_{2}$ & $\begin{array}{l}1.97-2.00, \text { dd }(12.8,3.0) \\
1.69-1.73, \text { dd }(12.8,3.0)\end{array}$ & $40.4, \mathrm{CH}_{2}$ & $\begin{array}{l}1.87, \mathrm{dd}(12.8,3.2) \\
1.62, \mathrm{dd}(12.8,8.0)\end{array}$ & $41.2, \mathrm{CH}_{2}$ & $1.66-1.70, \mathrm{~m}$ \\
\hline 10 & $74.2, \mathrm{C}$ & & $74.5, \mathrm{C}$ & & $72.6, \mathrm{C}$ & \\
\hline 11 & $40.8, \mathrm{CH}_{2}$ & $\begin{array}{l}1.89, \text { br. d (11.0) } \\
1.62-1.64, \mathrm{~m}\end{array}$ & $41.5, \mathrm{CH}_{2}$ & $\begin{array}{l}1.89-1.92, \mathrm{~m} \\
1.53-1.56^{*}\end{array}$ & $42.6, \mathrm{CH}_{2}$ & $1.50-1.54, \mathrm{~m}$ \\
\hline 12 & 24.6, $\mathrm{CH}_{2}$ & $\begin{array}{l}1.49-1.55, \mathrm{~m} \\
1.20-1.34, \mathrm{~m}\end{array}$ & 21.6, $\mathrm{CH}_{2}$ & $\begin{array}{l}1.53-1.56^{*} \\
1.31-1.35, \mathrm{~m}\end{array}$ & $23.3, \mathrm{CH}_{2}$ & $2.10-2.15, \mathrm{~m}$ \\
\hline 13 & $48.7, \mathrm{CH}$ & $2.34, \mathrm{dt}(12.5,2.7)$ & $55.9, \mathrm{CH}$ & $1.76, \mathrm{dt}(12.8,2.0)$ & $125.9, \mathrm{CH}$ & $5.15, \mathrm{t}(6.9)$ \\
\hline 14 & $152.5, \mathrm{C}$ & & 74.0, C & & $135.0, \mathrm{C}$ & \\
\hline 15 & $37.4, \mathrm{CH}_{2}$ & $2.09-2.25^{*}$ & $36.8, \mathrm{CH}_{2}$ & $\begin{array}{l}1.35-1.42, \mathrm{~m} \\
1.00, \mathrm{~m}\end{array}$ & $40.4, \mathrm{CH}_{2}$ & $1.96, \mathrm{t}(7.5)$ \\
\hline 16 & 27.7, $\mathrm{CH}_{2}$ & $2.09-2.25 *$ & $23.0, \mathrm{CH}_{2}$ & $\begin{array}{l}2.09-2.14, \mathrm{~m} \\
1.96-2.01, \mathrm{~m}\end{array}$ & 27.4, $\mathrm{CH}_{2}$ & $2.07 *$ \\
\hline 17 & $125.2, \mathrm{CH}$ & $5.16, \mathrm{t}(6.6)$ & $126.1, \mathrm{CH}$ & $4.98, \mathrm{t}(7.0)$ & $125.1, \mathrm{CH}$ & $5.10, \mathrm{t}(7.1)$ \\
\hline 18 & 131.9, C & & $130.9, \mathrm{C}$ & & 131.6, C & \\
\hline 19 & 17.7, $\mathrm{CH}_{3}$ & $1.60, \mathrm{~s}$ & 17.6, $\mathrm{CH}_{3}$ & $1.56, \mathrm{~s}$ & 17.7, $\mathrm{CH}_{3}$ & $1.58, \mathrm{~s}$ \\
\hline 20 & $25.8, \mathrm{CH}_{3}$ & 1.66 , br. s & $25.8, \mathrm{CH}_{3}$ & $1.59, \mathrm{~s}$ & $25.8, \mathrm{CH}_{3}$ & $1.65, \mathrm{~s}$ \\
\hline 21 & $109.7, \mathrm{CH}_{2}$ & $\begin{array}{l}4.64, \text { br. } s \\
4.28, \text { br. } s\end{array}$ & 27.3, $\mathrm{CH}_{3}$ & $1.13, \mathrm{~s}$ & $15.9, \mathrm{CH}_{3}$ & $1.62, \mathrm{~s}$ \\
\hline 22 & $29.1, \mathrm{CH}_{3}$ & $1.28, \mathrm{~s}$ & $29.0, \mathrm{CH}_{3}$ & $1.26, \mathrm{~s}$ & $27.5, \mathrm{CH}_{3}$ & 1.20. s \\
\hline 4-OH & & $7.96, \mathrm{~s}$ & & $7.91, \mathrm{~s}$ & & $8.05, \mathrm{~s}$ \\
\hline 6-OH & & & & & & $8.05, \mathrm{~s}$ \\
\hline $10-\mathrm{OH}$ & & & & & & $3.54, \mathrm{~s}$ \\
\hline 14-OH & & & & $3.30, \mathrm{~s}$ & & \\
\hline
\end{tabular}

a $\quad{ }^{1} \mathrm{H}$ NMR spectra were measured at $400 \mathrm{MHz}$, and ${ }^{13} \mathrm{C}$ NMR spectra at $100 \mathrm{MHz}$

b ${ }^{1} \mathrm{H}$ NMR spectra was measured at $500 \mathrm{MHz}$, and ${ }^{13} \mathrm{C}$ NMR spectra at $125 \mathrm{MHz}$

* Signals were overlapped

(MTT) (Sigma, St. Louis, MO). Briefly, $100 \mu \mathrm{L}$ of adherent cells were seeded into each well of a 96-well cell culture plate and allowed to adhere for $12 \mathrm{~h}$ before drug addition, while suspended cells were seeded just before drug addition, both with an initial density of $1 \times 10^{5}$ cells $/ \mathrm{mL}$ in 100 $\mu \mathrm{L}$ of medium. Each tumor cell line was exposed to the test compounds at various concentrations in triplicate for $48 \mathrm{~h}$, with DDP and toxal as positive controls. After the incubation, MTT $(100 \mu \mathrm{g})$ was added to each well, and the incubation continued for $4 \mathrm{~h}$ at $37^{\circ} \mathrm{C}$. The cells lysed with $200 \mu \mathrm{L}$ SDS after removal of $100 \mu \mathrm{L}$ of medium. The optical density of lysate was measured at $595 \mathrm{~nm}$ in a 96-well microtiter plate reader (Bio-Rad 680). The $\mathrm{IC}_{50}$ value of each compound was calculated by Reed and Muench's method [17].

Acknowledgment This project was supported by the National Natural Sciences Foundation of China (U1132607).

Conflicts of interest The authors declare no conflict of interest.

Open Access This article is distributed under the terms of the Creative Commons Attribution License which permits any use, 
distribution, and reproduction in any medium, provided the original author(s) and the source are credited.

\section{References}

1. Z.H. Ding, Z.J. Dong, J.K. Liu, Helv. Chim. Acta 84, 259-262 (2001)

2. B. Koch, W. Steglich, Eur. J. Org. Chem. 2007, 1631-1635 (2007)

3. M. Nukata, T. Hashimoto, I. Yamamoto, N. Iwasaki, M. Tanaka, Y. Asakawa, Phytochemistry 59, 731-737 (2002)

4. D.N. Quang, T. Hashimoto, Y. Arakawa, C. Kohchi, T. Nishizawa, G.I. Soma, Y. Asakawa, Bioorg. Med. Chem. 14, 164-168 (2006)

5. X.L. Yang, C. Qin, F. Wang, Z.J. Dong, J.K. Liu, Chem. Biodivers. 5, 484-489 (2008)

6. L. Zhang, Z.J. Dong, J.K. Liu, Acta Bot. Yunn. 31, 187-189 (2009)

7. T. Hashimoto, D.N. Quan, M. Nukada, M. Nukada, Y. Asakawa, Heterocycles 65, 2431-2439 (2005)
8. D.Q. Luo, H.J. Shao, H.J. Zhu, J.K. Liu, Z. Naturforschung C60, 50-56 (2005)

9. H. Kawagishi, A. Tanaka, K. Sugiyama, H. Mori, H. Sakamoto, Y. Ishoguro, K. Kobayashi, M. Uramoto, Phytochemistry 42, 547-548 (1996)

10. V. Hellwig, R. Nopper, F. Mauler, J. Freitag, J.K. Liu, Z.H. Ding, M. Stadler, Arch. Pharm. 336, 119-126 (2003)

11. M. Ye, J.K. Liu, Z.X. Lu, Y. Zhao, S.F. Liu, L.L. Li, M. Tan, X.X. Weng, W. Li, Y. Cao, FEBS Lett. 579, 3437-3443 (2005)

12. H.D. Zheng, P.G. Liu, Microbiol. China 33, 104-107 (2006)

13. S. Jones, D. Valette, Org. Lett. 11, 5358-5361 (2009)

14. M. Nakata, M. Arai, K. Tomooka, N. Ohsawa, M. Kinoshita, Bull. Chem. Soc. Jpn. 62, 2618-2635 (1989)

15. H. Ziffer, K.I. Kawai, M. Kasai, M. Imuta, C. Froussios, J. Org. Chem. 48, 3017-3021 (1983)

16. T. Mukaiyama, T. Shintou, K. Fukumoto, J. Am. Chem. Soc. 125, 10538-10539 (2003)

17. L.J. Reed, H. Muench, Am. J. Hyg. 27, 493-497 (1938) 